\title{
Developing E-Commerce for Micro Small Medium Enterprise (MSME) to Cope with Cultural Transformation of Online Shopping
}

\author{
Nadia Sigi Prameswari ${ }^{1}{ }^{\bowtie}$, Mohamad Suharto ${ }^{2}$ Narsen Afatara $^{1}$ \\ ${ }^{1}$ Faculty of Teacher Training and Education, Universitas Sebelas Maret, Surakarta, Indonesia \\ ${ }^{2}$ Faculty of Art and Design, Universitas Sebelas Maret, Surakarta, Indonesia
}

\section{Info Article}

History Article:

Received Juni 2017

Approved August 2017

Published September 2017

\section{Keywords:}

E-Commerce; MSME; Cultural

Transformation; Online Shopping.

\begin{abstract}
This study aims to examine factors contributing to societies' tendencies to choose online shopping, the characteristics of e-commerce needed by societies and obstacles faced by MSME in handling business competition. E-commerce is a set of dynamic technology, application and business process which connects certain companies, consumers and communities through electronic transaction. Trade of goods, services and information is performed electronically. The development of E-commerce system for MSME aims to change its culture which still relies on conventional purchasing into online shopping, improve MSME's sales in order to promote, market and sell products to internet users through website without any space and time limits. The research subjects are people involving in MSME and communities of Jebres village, Surakarta. This study applies qualitative paradigm. The research subjects were taken using purposive sampling techniques. Data were collected using various techniques: structured interview, questionnaire, observation and content analysis or archive analysis. Data were later analyzed using four stages, namely data reduction, classification, data presentation and verification.
\end{abstract}

\section{Pengembangan E-Commerce untuk UMKM dalam Menghadapi Tranformasi Budaya Belanja Online}

\begin{abstract}
Abstrak
Tujuan dari penelitian ini adalah mengkaji faktor-faktor yang menjadikan masyarakat lebih memilih berbelanja online, karakteristik online media yang disukai masyarakat dan kendala-kendala yang dihadapi UMKM dalam menghadapi persaingan usaha. Ecommerce merupakan satu set dinamis teknologi, aplikasi, dan proses bisnis yang menghubungkan perusahaan, konsumen, dan komunitas tertentu melalui transaksi elektronik. Perdagangan barang, pelayanan dan informasi dilakukan secara elektronik. Pengembangan sistem E-commerce untuk UMKM bertujuan merubah budaya UMKM yang masih mengandalkan pembelian konvensional menjadi online shop, meningkatkan penjualan UMKM dalam rangka mempromosikan, memasarkan, dan menjual produk kepada pengguna internet tanpa dibatasi ruang dan waktu. Penelitian ini mengambil subjek pelaku UMKM dan masyarakat di kelurahan Jebres kota Surakarta. Penelitian ini merupakan penelitian kualitatif. Subyek dipilih secara purposive sampling. Pengumpulan data dilakukan melalui teknik wawancara terstruktur, kuesioner, observasi, dan analisis isi dokumen/ arsip. Data dianalisis melalui tahapan reduksi, klasifikasi, sajian data dan verifikasi.
\end{abstract}

JEL Classification: M3, M31, M37

How to Cite: Prameswari, N. S., Suharto, M \& Afatara, N. 2017. Developing E-Commerce for Micro Small Medium Enterprise (MSME) to Cope with Cultural Transformation of Online Shopping. Jurnal Dinamika Manajemen. 8 (2): 188-198. 
Nadia Sigi Prameswari, et al. / Developing E-Commerce for Msme in..

\section{INTRODUCTION}

Globalization and free trade are challenges for Micro, Small and Medium Enterprise (MSME) to maintain its existence. If MSME does not quickly get ready, it is feared that it can't compete in the market place and later will go out of business. This is so for MSME plays significant roles in developing economy in many countries around the globe (Ramanathan et al., 2012). Therefore, MSME needs to improve itself and establish long-term relationship with customers (Ghobakhloo et al., 2011).

Information technology offers many advantages for MSME to improve its productivity and marketing, as well as increase its opportunity to cooperate with other business players (Neti, 2011). MSME plays important roles in creating job opportunities and developing the economy. The effects of globalization on the development in new business environment created by globalization are highly important for developing and developed countries (Savrul et al., 2014).

The main advantages of E-commerce are time efficiency when doing significant transaction and ease of access from around the world (Khan, 2016). E-commerce will provide companies with access to a number of greater suppliers since the increasing number of suppliers will reduce the inflationary pressure (Daniel \& Wilson, 2002). Moreover, E-commerce will be able to improve product marketing and expand market (Farida et al., 2017).

The main uses of E-commerce which are not well-anticipated by this sector are business efficiency, image building, competitive excellence, process automation improvement and business cycle improvement (Kuzic et al., 2002). E-commerce also affects commercial real estate in numerous ways including planning, designing and lay-outing commercial development (Zhang et al., 2015).

E-commerce has positive effects on customer-based development (Karagozoglu \& Lindell, 2004). The use of E-commerce is capable of improving customer's satisfaction and the availability of resources, as well as reducing errors (Kumar \& Petersen, 2006). In addition, Ecommerce helps MSME identify the benefits of operating system, helping improve overall working performance (Love \& Irani, 2004).

Kabanda and Brown (2017) mentions that by using mobile technology repeatedly, MSME owner has developed extensive use of Ecommerce to reach its functions such as for business communication and selling and purchasing activities. The increasing value of E-commerce can help MSME to reap a profit to create value added services, new services and new business model and broaden the business (Ueangkomsate, 2015). Some efforts have to be made by Indonesian MSME to develop itself at maximum level to be ready and successful to go global by adopting E-commerce (Moertini, 2012).

E-commerce becomes important thing for transaction in life in 21st century (Kurnia et al., 2015). Various services in E-commerce have developed in the last few years and consumers have adopted the services as parts of their everyday life and therefore, many people use E-commerce (Sharma \& Lijuan, 2014). E-commerce is required and can't be developed without organizational purpose and strategies for both shortterm and long-term advantages. E-commerce is still considered new idea for MSME, consumers and the government (Jahanshahi et al., 2013). The more increasing uses of online media influence consumers' behavior and business players today and these will change extremely in the future (Gupta, 2014).

Online shopping occupies functional and utilitarian dimensions, like 'ease of use' and 'uses', which make it widely used (Perea y Monsuwé et al., 2004). It will reduce transportation cost and shopping time. This factor finally makes online shopping habit today's trend. Lichtenthal and Eliaz (2003) states that online business communication system is the only way to completely convey message to customers. Moreover, $\mathrm{Ng}$ (2013) argues that online business brings business players closer to their customers.

The numbers of internet users increase due to its features which enable them access 
many things easily from all parts of the world (Dinu \& Dinu, 2014). Improving profitability, winning market segment, improving customer service and providing products more quickly are some of the advantages of organizational performance which perhaps come true with electronic commerce (Watson et al., 2008). Kim and Peterson (2017) explains that the future of business-to-consumer E-commerce will weaken without online trust. E-commerce improves competitiveness of companies selling and purchasing online and as the result, when crisis happens, these companies will probably survive better when facing the negative impacts of the crisis (Savrul \& Kılıç, 2011).

Previous studies have recorded that Ecommerce contributes significantly to central and regional economic growth. After the rapid growth of E-commerce in business world, brand and branding become more important components of Indian and Malaysian economy ( Jahanshahi \& Zhang, 2013). Culture has indeed special effects on mobile commerce adoption, which explains the difference of today's development and shows evolutionary direction in the future (Zhang et al., 2012). E-commerce has changed significantly the ways of companies running business in Hong Kong (Gunasekaran \& Ngai, 2005). The UK has successfully developed such services from E-commerce (Daniel \& Wilson, 2002).

Indonesia is one of countries with an explosion of internet users. Internet users in 1998 were only 500 thousand people, but the number increased dramatically in the early 21 st century reaching around 61 million users (Karimuddin, 2012). The increasing numbers of internet users place Indonesia at the fourth position of country with the most internet users in the world. The use of E-commerce in Indonesia has influenced some factors among others are the benefits received, technology readiness, owner's innovation, owner's experience with IT and owner's capabilities using IT (Rahayu \& Day, 2015).

MSME in Indonesia has important role in the national economic development. It can be tracked from the amount of employment and employment opportunities from MSME. The research object is MSME because it is the economic support especially when economical crisis 1998, so that Indonesia economic status can be risen up to the higher level. At that time, only MSME can survive in economical crisis (Wahyuningsih, 2009; Riani, 2011; Hillery, 2012; Mujiyana et al., 2012; Sudaryanto \& Wijayanti, 2013; Tedjasuksmana, 2014; Hafni \& Rozali, 2015; Suci, 2017).

Data from Ministry of Cooperatives and Small and Medium Enterprises in 2013 explain that the MSME contribution toward creation of national foreign exchange through non oil and gas exports experience the improvement amount about Rp50.35 trillion or 30.09\% that is about Rp189.46 trillion or $18.17 \%$ from the total export value of national non oil and gas exports. Data explain that the owners of MSME in Indonesia employ about 100,096,270 employee or $93.04 \%$ from the total employment (Kementerian Koperasi dan UMKM, 2017).

This research is very important to know about the cultural transformation of MSME that still rely on conventional shopping method become online shopping and expected to improve the sales.

\section{METHOD}

The type of this research is explanatory research. Subject and location of this research participants are Micro, Small and Medium Enterprise (MSME) players and societies in Jebres Village, Surakarta. Data of this study can be collected at a certain time at once or at multiphase depending on the characteristics of the problems which are going to be responded. This study applies qualitative method.

Data in this research were collected by conducting structured interview and getting to MSME and societies in Jebres Village, particularly in the area of Universitas Sebelas Maret campus, directly. The researchers carried out the structured interviews to 240 respondents, comprising 120 MSME respondents and 120 societies in Jebres, Surakarta. Data of the struc- 
Nadia Sigi Prameswari, et al. / Developing E-Commerce for Msme in..

tured questions were gathered within a month. Every respondent required 25 minutes on average to complete all questions. Data were gathered using various techniques: (1) structured interview, (2) questionnaire, (3) observation and (4) content or document analysis/ archive analysis. They were later analyzed with some stages, namely data reduction, categorization, data presentation and verification.

\section{RESULT AND DISCUSSION}

\section{General Description of Respondents}

Respondents in this research are societies and MSME in Jebres village, Surakarta. The data in this research are collected by using questionnaire and interview. The aims of interview are to strengthen the questionnaire data validity and digging further Information.

Questionnaires were distributed using people-assisted-method, in which respondents were assisted when filling out the questionnaires and conducting structured interviews, so that all questionnaires were responded and returned. A total of 240 structured interviews were successfully carried out since the researchers directly got into the respondents.

\section{Interviews with Societies Respondents}

There are 120 societies in Jebres that become respondents in this research (Table 1).
Most of them are female ( 83 people). The majority of respondents are in the age of 20-29 with educational background of Senior High School.

Table 1. Profile of Societies Respondents

\begin{tabular}{lc}
\hline Gender & Number of Respondent \\
\hline Male & 37 \\
Female & 83 \\
Total & 120 \\
\hline Age (years old) & Number of Respondent \\
\hline $10-19$ & 29 \\
$20-29$ & 87 \\
$30-39$ & 4 \\
Total & 120 \\
\hline Education & - \\
\hline Primary & 1 \\
Secondary & 87 \\
Senior High School & 3 \\
Diploma & 28 \\
Bachelor & - \\
Other & 120 \\
Total & \\
\hline
\end{tabular}

In reference to the results of interviews (Tabel 2), it follows that $98.3 \%$ of MSMEs and societies in Jebres village of Surakarta got to know online shops. $80 \%$ Societies in Jebres villa-

Table 2. Online Shop Phenomenon

\begin{tabular}{lcc}
\hline \multicolumn{1}{c}{ Indicators } & Frequency & Percentage \\
\hline Got to know online shops. & 118 & $98.3 \%$ \\
$\begin{array}{l}\text { Did online shopping. } \\
\text { Chose online shops due to easy, practicable and time- }\end{array}$ & 96 & $80 \%$ \\
efficient transaction process. & 95 & $79 \%$ \\
Got to know online shops from friends and relatives. & 107 & $89.2 \%$ \\
Have got to know online shops for more than 1 year. & 100 & $83.3 \%$ \\
$\begin{array}{l}\text { Need internet access for online transactions through mobile } \\
\text { phone. }\end{array}$ & 92 & $76.7 \%$ \\
$\begin{array}{l}\text { Respondents' trust in their online transactions or goods to } \\
\text { be delivered. }\end{array}$ & 39 & $32.5 \%$ \\
\hline
\end{tabular}


Table 3. Consumers' Behaviors Actualized through Online Shops

\begin{tabular}{lrc}
\hline \multicolumn{1}{c}{ Indicators } & Percentage \\
\hline Respondents are satisfied about online shopping. & 105 & $87.5 \%$ \\
$\begin{array}{l}\text { Respondents make online purchases less than 5 times a month. } \\
\text { Respondents have spent less than IDR 500,000 in a month to make } \\
\text { online purchases. }\end{array}$ & 89 & $74.2 \%$ \\
$\begin{array}{l}\text { Online shopping does not influence the change in consumption } \\
\text { lifestyle. }\end{array}$ & 83 & $68.3 \%$ \\
$\begin{array}{l}\text { Respondents perceive no changes in consumtion patterns due to } \\
\text { online shopping. }\end{array}$ & 77 & $69.2 \%$ \\
\hline
\end{tabular}

Table 4. Factors Causing the Emergence of Online Consumption Behaviors

\begin{tabular}{lcc}
\hline \multicolumn{1}{c}{ Indicators } & Frequency & Percentage \\
\hline $\begin{array}{l}\text { Before getting to know online shops, respondents fulfilled their con- } \\
\text { sumption needs by making purchase in the nearest store. }\end{array}$ & 104 & $86.6 \%$ \\
Respondents are happy with online shopping experience. & 74 & $61.7 \%$ \\
Respondents suggest online shops to their closest persons of friends. & 80 & $66.7 \%$ \\
Respondents exchange information on online shops with their friends. & 86 & $71.7 \%$ \\
\hline
\end{tabular}

ge started to do online shopping. Most of them chose online shops due to easy, practicable and time-efficient transaction process. The results of interviews indicate that they got to know online shops from friends and relatives. The respondents said that they had got to know online shops for more than 1 year. A medium used by $76.7 \%$ of the respondents to gain access to internet for online transaction is a mobile phone. However, many respondents decide not to make online transactions due to their lack of trust in the products to be delivered.

After experiencing online transactions, $87.5 \%$ of the respondents claimed to feel satisfied (Table 3 ). It can be concluded from the results of the interviews and questionnaires that $74.2 \%$ respondents make online purchase less than 5 times a month. They also spend less than IDR 500,000 a month to shop online. However, they believe that online shopping does not influence the change in their consumption lifestyle as well as in their consumption patterns.
Data of interview results (Table 4) reveal that before getting to know online shops, $86.6 \%$ of the respondents fulfilled their consumption needs by making purchase in the nearest store. After globalization, online shops are widely accessed and respondents feel happy to do online shopping. The respondents also disseminate information on online shops and suggest to the closest persons or friends. This way, the respondents can exchange information on online shops.

Table 5 shows the statements of respondents. In reference to the results of interviews, respondents are interested in online shopping with regards to quick service and efficiency. In addition, they think that online shopping gives more benefits, including practicable and timeefficient easy shopping and many choices offered when it comes to products or goods.

The results of the interviews in Figure 1 show that most respondents do not use personal websites since they do not provide reliable information. Similarly, they do not make 
Nadia Sigi Prameswari, et al. / Developing E-Commerce for Msme in..

Table 5. Statement of Respondents

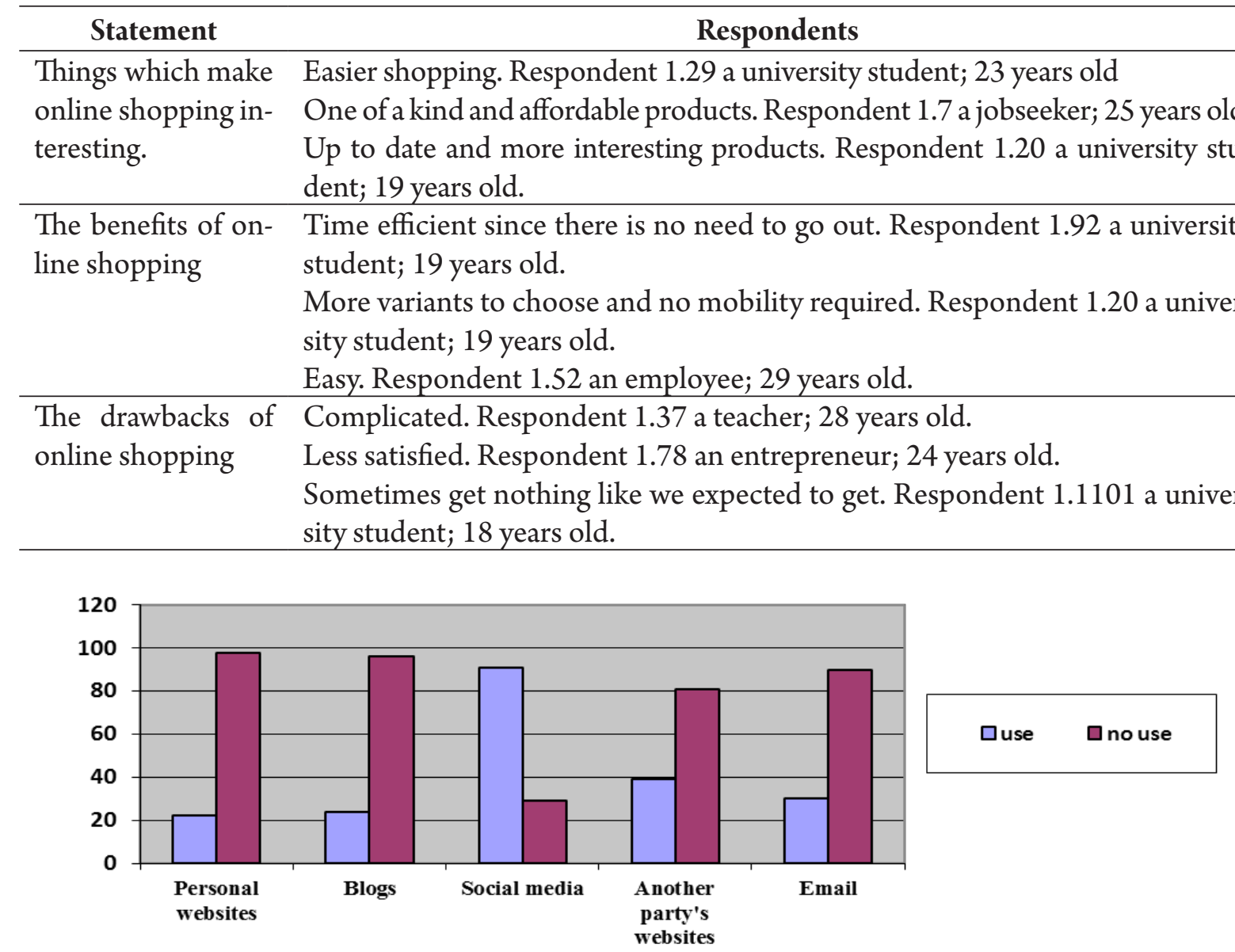

Figure 1. The Use of E-Commerce Media

use of blog as online transaction medium due to respondents' lack of trust in online transaction service and personal vulnerability to such crimes as frauds. Social media, such as facebook, instagram, twitter, etc, are widely used by the respondents due to easy-to-access information and sellers' fast responses.

A number of benefits of using E-commerce gained by MSMEs present as strong push factors to continuously use E-commerce for developing products, making communication with consumers, distributors and suppliers, as well as expanding market networks. This fact is in line with a previous research denoting that perception on the benefits of the use of information technology is one of push factors for SMEs to make use of media of information technology (Alam \& Noor, 2009).
E-commerce is one medium to ease interactive communication between an entrepreneur and such parties as consumers, distributors, suppliers and other related parties. It is useful in connecting information and communication from producers to consumers wherever they are, even at whatever distance. In addition, it is a potential medium to find new customers and to build a product brand image (Alam \& Noor, 2009; Mohammad \& Ismail, 2009; Merril et al., 2011). Moreover, the development in technologies enables internet to be accessed by whoever wherever they are. The use of information technology and social media, therefore, is helpful for SMEs to continuously develop their products and to make business decision (Miller \& Lammas, 2009). The present research indicates that the benefits of social media gained by 
owners/ management of MSMEs include: 1) an ease in making effective communication among management of smes, consumers and suppliers, 2) an increase in marketing and expansion of market share, 3) an enhancement of knowledge and of business decision. Such findings are in accordance with a previous research explaining that the use of information technology allows to increase entrepreneurs' opportunity to improve their productivity, strengthen competitiveness and consolidate the relationship among entrepreneurs including suppliers and distributors (Ghobakhloo et al., 2011).

Interviews with Respondents Consisting of Owners of MSMEs

There are 120 respondents consisting of owners of MSMEs in this research (Table 6). Most of them have job tenure less than 1 year (34 respondents). Based on the results of the interviews, several E-commerce media used to support business activities of MSMEs are identified in Table 7.
Table 6. Respondent Profile

Job tenure The Number of Respondents

\begin{tabular}{lr}
$<1$ year & 34 \\
$1-3$ years & 25 \\
$3-5$ years & 20 \\
5-10 years & 26 \\
$>10$ years & 14 \\
Not re- & 1 \\
sponding & \\
Total & 120 \\
\hline
\end{tabular}

Table 7. Media Uses

\begin{tabular}{lc}
\hline \multicolumn{1}{c}{ Media } & $\begin{array}{c}\text { The Percentage of Respon- } \\
\text { dents Using the Media }\end{array}$ \\
\hline Personal websites & $5 \%$ \\
Blogs & $3 \%$ \\
Social media & $36 \%$ \\
$\begin{array}{l}\text { Another party's } \\
\text { websites }\end{array}$ & $6 \%$ \\
\hline
\end{tabular}

Table 8. The Total Number of Respondents: 120 MSMEs

\begin{tabular}{lcc}
\hline \multicolumn{1}{c}{ Statement } & Frequency & Percentage \\
\hline MSMEs got to know E-commerce. & 44 & $36 \%$ \\
MSMEs make use of E-commerce & 46 & $38 \%$ \\
Awareness of benefits of using E-commerce & 40 & $33 \%$ \\
\hline
\end{tabular}

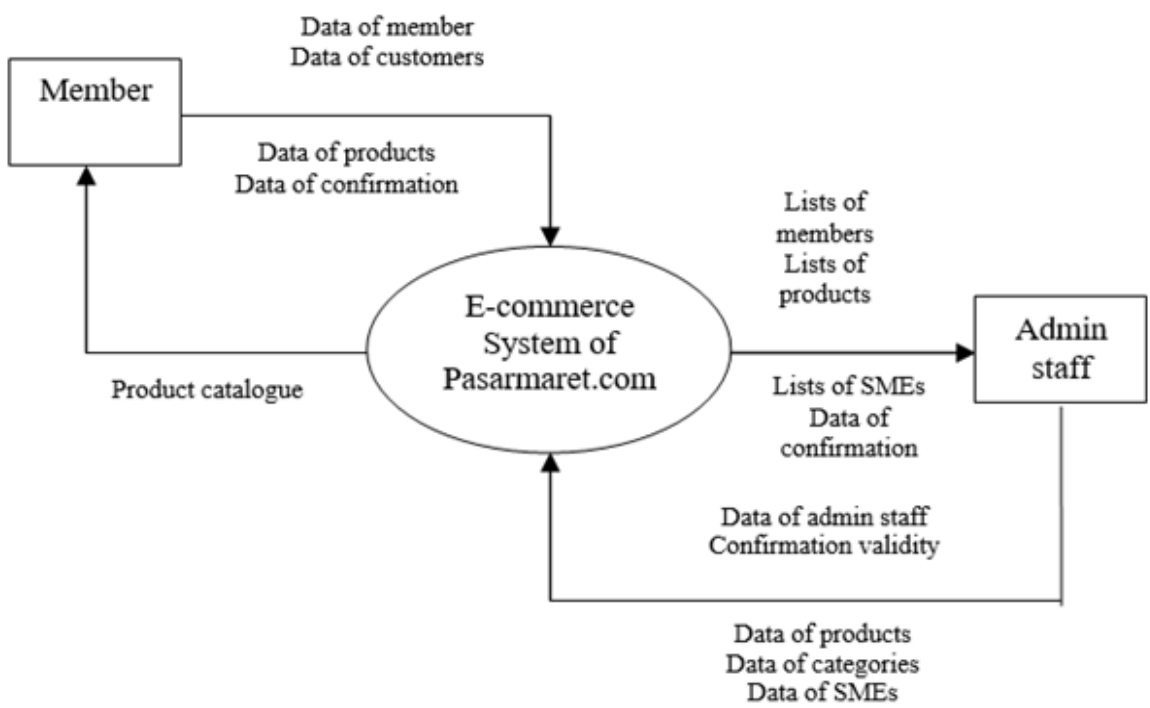

Figure 2. Context Diagram of E-Commerce System 
Nadia Sigi Prameswari, et al. / Developing E-Commerce for Msme in.

The results of the interviews reveal that $5 \%$ of MSMEs in Jebres Village uses personal websites, $4 \%$ uses blogs, $36 \%$ uses social media and $6 \%$ uses another party's websites (Table 7). Fewer respondents, particularly those in area of UNS, make use of websites due to their insufficient knowledge to operate website and inadequate capital to market their products through internet networks.

The results of the interviews reveal that $36 \%$ of MSMEs around areas of UNS got to know E-commerce, 38\% make use of E-commerce for online transaction and $33 \%$ are awa- re of benefits of using E-commerce (Table 8). However, MSMEs have been unable to use Ecommerce well despite awareness of potentials yielded by E-commerce. They, however, can still develop their business and compete in global market using E-commerce.

\section{The Development of E-commerce of Pasarma- ret.com}

\section{Context Diagram}

Context diagram refers to a modeling diagram which illustrates system in a wholeness and relatedness with external entities (Yourdon

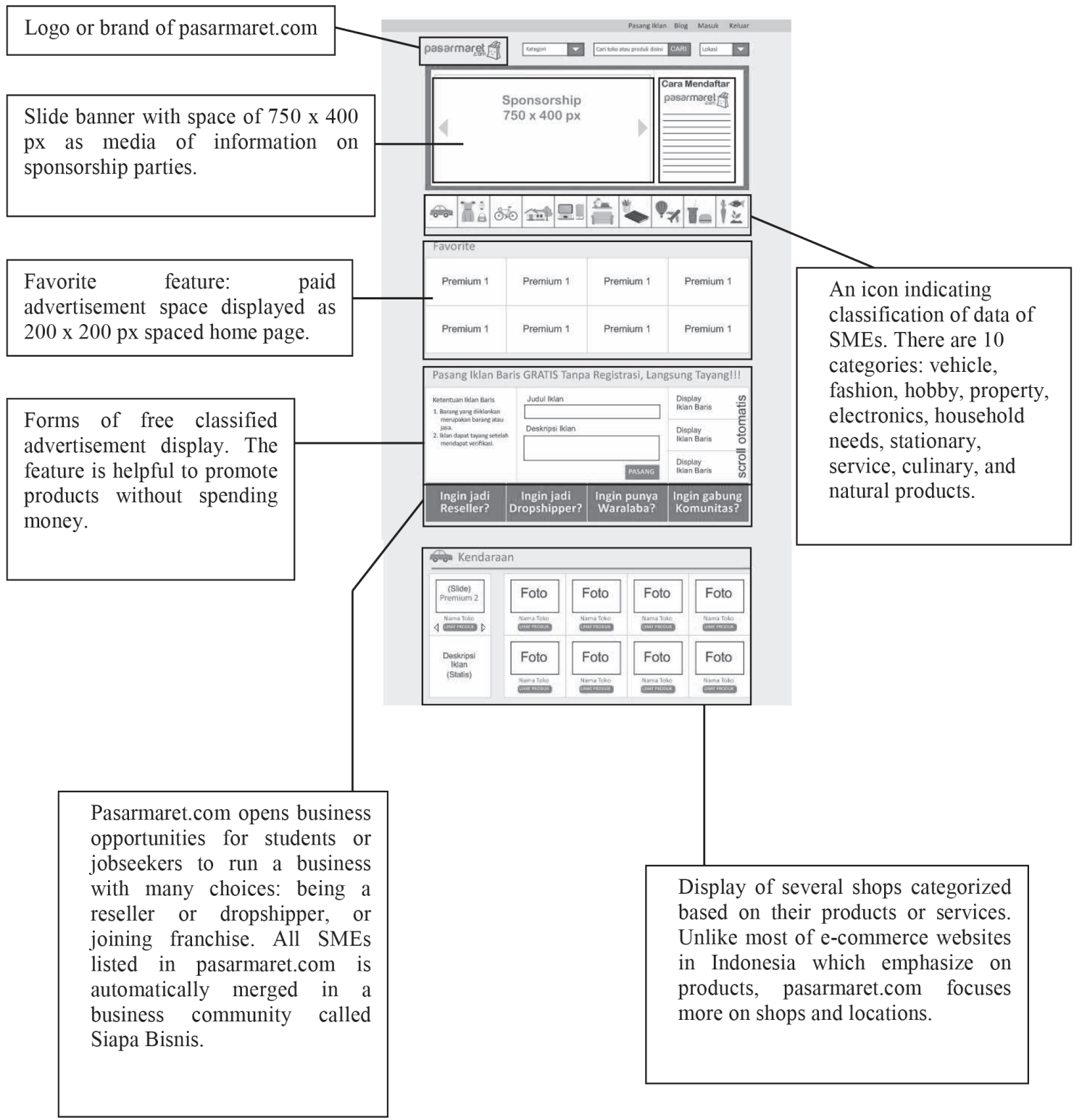

Figure 3. E-commerce Website Model of pasarmaret.com 
\& Larry, 1975). The Figure 2 and Figure 3 demonstrates context diagram of E-commerce system and E-commerce website model of pasarmaret.com.

\section{CONCLUSIONAND RECOMMENDATION}

The present research shows that societies are enthusiastic about the use of E-commerce and many consumers start to shop online considering its easy process and time efficiency. Based on the research, the most favorite E-commerce media that used by respondents is social media, because it is easy to access. Also, because of the fast respond from seller makes social media like facebook, instagram, twitter, etc widely used by respondents.

From the result of the research explain that the problems that faced by MSME in business competition is there are many MSMEs still not utilizing E-commerce to improve the business to the higher level. Many MSMEs have not yet made use of E-commerce well despite awareness of its great potentials to develop and maintain the enterprises due to lack of insight and knowledge on the current developing technologies. The development of E-commerce is highly required to meet consumers' needs and to enhance MSMEs. Clearly, E-commerce plays a vital role in economy of many countries, particularly in MSMEs in increasing the number of transactions.

The limitations of this research are this research only researching about: (1) the cultural transformation of conventional shopping to online shop, (2) the problems that are faced by MSME, (3) the most suitable characteristics of E-commerce website for MSME so that from these results of this research are developed become E-commerce media, www.pasarmaret. com that accommodates all of the consumers and MSME's desires. Therefore, the suggestion for the future research is to develop the research in the next step by focusing the impact of MSME that has utilized E-commerce www.pasarmaret.com.

\section{REFERENCES}

Alam, S. S \& Noor, M. K. M. 2009. ICT Adoption in Small and Medium Enterprises: an Empirical Evidence of Service Sectore in Malaysia. International Journal of Business and Management. 4 (2): 112-125.

Daniel, E \& Wilson, H. 2002. Adoption Intention and Benefits Realised: a Study of E-Commerce in UK SMEs. Journal of Small Business and Enterprise Development. 9 (4): 331-348.

Dinu, G \& Dinu, L. 2014. Using Internet as a Commercial Tool: a Case Study of E-Commerce in Resita. Procedia Engineering. 69: 469-476.

Farida, N., Naryoso, A \& Yuniawan, A. 2017. Model of Relationship Marketing and E-Commerce in Improving Marketing Performance of Batik SMEs. Jurnal Dinamika Manajemen. 8 (1): 20-29

Ghobakhloo, M., Sabouri, M. S., Hong, T. S \& Zulkifli, N. 2011. Information Technology Adoption in Small and Medium-Sized Enterprises; an Appraisal of Two Literature. Interdisciplinary Journal of Research in Business. 1 (7): 53-80.

Gunasekaran, A \& Ngai E. W. T. 2005. E- commerce in Hong Kong: an Empirical Perspective and Analysis. Internet Research. 15 (2): 141-159.

Gupta, A. 2014. E-Commerce: Role of E-Commerce in Today's Business. International Journal of Computing and Corporate Research. 4 (1).

Hafni, R \& Rozali, A. 2015. Analisis Usaha Mikro, Kecil dan Menengah (UMKM) Terhadap Penyerapan Tenaga Kerja Di Indonesia. Ekonomikawan: Jurnal Ilmu Ekonomi dan Studi Pembangunan. 15 (2): 77-96.

Hillery, D. 2012. Penerapan Teknologi Informasi dan Komunikasi (TIK) pada UMKM dengan Menggunakan Technology Acceptance Model (TAM) (Studi Kasus Di Depok dan Qingdao). Procedeengs. Presented at Seminar Ilmiah Nasional Komputer dan Sistem Intelijen (KOMMIT 2012), September, 7 2012, Universitas Gunadarma-Depok, 18 19 September 2012.

Jahanshahi, A. A., Zhang, S. X \& Brem, A. 2013. E-Commerce for SMEs: Empirical Insights from Three Countries. Journal of Small Business and Enterprise Development. 20 (4): 849-865. 
Nadia Sigi Prameswari, et al. / Developing E-Commerce for Msme in..

Kabanda, S \& Brown, I. 2017. A Structuration Analysis of Small and Medium Enterprise (SME) Adoption of E-Commerce: the Case of Tanzania. Telematics and Informatics. 34 (4): 118-132

Karagozoglu, N \& Lindell, M. 2004. Electronic Commerce Strategy, Operations and Performance in Small Medium-Sized Enterprises. Journal of Small Business and Enterprice Development. 11 (3): 290-301.

Karimuddin, A. 2012. R. E. MarkPlus Insight: Jumlah pengguna internet di Indonesia capai 61 juta orang. Available at: https://dailysocial. id/post/markplus-insight-jumlah-pengguna-internet-di-indonesia-capai-61-jutaorang/. May 26, 2017.

Kementerian Koperasi dan UMKM. 2017. Data UMKM dan Usaha Besar 2012-2013. Available at: http://www.depkop.go.id/berita-informasi/data-informasi/data-umkm/. May 12, 2017.

Khan, A. G. 2016. Electronic Commerce: a Study on Benefits and Challenges in An Emerging Economy. Global Journal of Management and Business Research. 16 (1): 18-22.

Kim, Y \& Peterson, A. R. 2017. A Meta-Analysis of Online Trust Relationship in E-Commerce. Journal of Interactive Marketing. 38: 44-54

Kumar, S \& Petersen, P. 2006. Impact of E-Commerce in Lowering Operational Cost and Raising Customer Satisfaction. Journal of Manufacturing Technology Management. 17 (3): 283-302.

Kurnia, S., Choudrie, J., Mahbubur, R. M \& Alzagooul, B. 2015. E-Commerce Technology Adoption: a Malaysian Grocery SME Retail Sector Study. Journal of Business Research. 68 (9): 1906-1918.

Kuzic, J., Fisher, J \& Scollary, A. 2002. Electronic Commerce Benefits, Challenges and Succes Factors in the Australian Banking and Finance Industry. ECIS Proceedings. Presented at European Conference on Information System (ECIS), Gdansk, Poland, June 6-8, 2002.

Lichtenthal, J. D \& Eliaz, S. 2003. Internet integration in Business Marketing Tactics. Industrial Marketing Management. 32 (1): 3-13.

Love, P. E. D \& Irani, Z. 2004. An Exploratory Study of Infomation Technology Evaluation and Benefit Management Practices of SMEs in the Construction Industry. Infomation ${ }^{2}$ Mangement. 42 (1): 227-242.

Merril, T., Latham, K., Santalesa, R \& Navetta, D. 2011. Social Media: the Business Benefit may be Enermous, but can the Risks-Reputation, Legal, Operational be Mitigated? Information Law Group. April: 1-12.

Miller, R \& Lammas, N. 2009. Social Media and its Implication for Viral Marketing. Asia Pacific Public Relation Journal. 11: 1-9.

Moertini, S. V. 2012. Small Medium Enterprises: On Utilizing Business-to-Business E-Commerce to Go Global. Procedia Economics and Finance. 4: 13-22.

Mohammad, R \& Ismail, N. A. 2009. Electronic Commerce Adoption in SME: the Trend of Prior Studies. Journal of Internet Banking and Commerce. 14 (2): 1-16.

Mujiyana, M., Sularto, L \& Mukhyi, M. A. 2012. Pengaruh Penerapan Periklanan di Internet dan Pemasaran Melalui E-Mail Produk UMKM di Wilayah Depok. J@TI Undip: Jurnal Teknik Industri. 7 (3): 161-168.

Neti, S. 2011. Social Media and its role in Marketing. International Journal of Enterprise Computing and Business Systems. 1(2): 1-15.

$\mathrm{Ng}$, C. S. P. 2013. Intention to Purchase on Social Commerce Websites Across Cultures: A Cross-Regional Study. Information \& Management. 50 (8): 609-620.

Perea y Monsuwé, T., Dellaert, B. G \& De Ruyter, K. 2004. What Drives Consumers to Shop online? a Literature Review. International Journal of Service Industry Management. 15 (1): 102-121.

Rahayu, R \& Day, J. 2015. Determinanat Factors of E-Commerce Adoption by SMEs in Developing Country: Evidence from Indonesia. Procedia-social and Behavioral Sciences. 195: 142-150.

Ramanathan. R., Ramanathan, U \& Hsiao, H. L. 2012. The Impact of E-Commerce on Thaiwanese SMEs: Marketing and Operations Efeect. International Journal of Production Economics. 140 (2): 934-943.

Riani, N. Z. 2011. Identifikasi Permasalahan dan Kerangka Pengembangan Kluster UMKM Sandang di Bukittinggi Sumatera Barat. Jurnal TINGKAP. 7 (1): 51-64.

Savrul, M., Incekara, A \& Sener, S. 2014. The Potential of E-Commerce for SMEs in a Glo- 
balizing Business Environment. ProcediaSocial and Behavioral Sciences. 150: 35-45.

Savrul, M \& Kılıç, C. 2011. E-Commerce As an Alternative Strategy in Recovery from the Recession. Procedia Social and Behavioral Sciences. 24: 247-259.

Sharma, G \& Lijuan, W. 2014. Ethical Perspectives on E-Commerce: an Empirical Investigation. Internet Resesarch. 24 (4): 414-435.

Suci, Y. R. 2017. Perkembangan UMKM (Usaha Mikro Kecil Dan Menengah) di Indonesia. Jurnal Ilmiah Cano Ekonomos. 6 (1): 51-58.

Sudaryanto, R \& Wijayanti, R. R. 2013. Strategi Pemberdayaan UMKM Menghadapi Pasar Bebas ASEAN. Pusat Kebijakan Ekonomi Makro. Badan Kebijakan Fiskal. Kementerian Keuangan, Jakarta.

Tedjasuksmana, B. 2014. Potret UMKM Indonesia Menghadapi Masyarakat Ekonomi ASEAN 2015. Presented at the 7th NCFB and Doctoral Colloquium 2014 towards a New Indo- nesia Business Architecture, Faculty of Business and Postgraduate UKWMS.

Ueangkomsate, P. 2015. Adoption E-Commerce for Export Market of Small ad Medium Enterprise in Thailand. Procedia-social and Behavioral Sciences. 207: 111-120.

Wahyuningsih, S. 2009. Peranan UKM dalam Perekonomian Indonesia. Jurnal MEDIAGRO. 5 (1): 1-14.

Watson, R. T., Berthon, P \& Pitt, L. F. 2008. Electronic Commerce: the Strategic Perspective. Zurich: Jacobs Foundation.

Yourdon, E \& Larry, C. 1975. Structured Design. New York: Yourdon Press.

Zhang, D,. Zhu, P \& Ye, Y. 2015. The Effects of ECommerce on the Demand for Commercial Real Estate. Cities. 51: 106-120

Zhang, L,. Zhu, J \& Liu, Q. 2012. A Meta-Analysis of Mobile Commerce Adoption the Moderating Culture. Computers in Human Behavior. 28(5): 1902-1911. 